\title{
Traducción y mediación: la obra dispersa de Gilberto Owen
}

\author{
Antonio Cajero Vázquez \\ El Colegio de San Luis \\ acajeroy@hotmail.com
}

\begin{abstract}
Resumen: La mayoría de los integrantes del "grupo sin grupo", mejor conocido como Contemporáneos, practicó la traducción como una función más de sus inclinaciones poligráficas. En este sentido, Gilberto Owen fue un profuso traductor del inglés y del francés en diferentes publicaciones de México y Colombia. En este artículo, como una contribución a la biografía y a la crítica en torno a la obra del autor de Línea, estudio las traducciones que Owen publicó a lo largo de su vida, incluidas tres desconocidas. A sesenta ańos de la publicación de Poesía y prosa (1953), considero que la producción de Owen sigue en permanente crecimiento y estas traducciones así lo demuestran.
\end{abstract}

Aвstract: Most members of the "grupo sin grupo", best known as Contemporáneos, practiced translation as a function of their polygraphic inclinations. In this sense, Gilberto Owen was a profuse translator of English and French in various publications of Mexico and Colombia. In this article, as a contribution to the biography and criticism about the author of Linea, I study the translations that Owen published through his life, including three that are unknown. Sixty years after the publication of Poesia y prosa (1953), I consider that the production of Owen is constantly growing and these translations prove it.

Palabras Clave: Gilberto Owen, El Tiempo, obras, traducciones, mediador. KeYwords: Gilberto Owen, El Tiempo, works, translations, mediator.

Igual que otros integrantes de Contemporáneos, Gilberto Owen desempeñó un activo papel de mediador en la República Mundial de las Letras, ya como crítico, ya como traductor. Ambas actividades, según Pascale Casanova, resultan fundamentales en la conformación del patrimonio literario nacional e internacional, porque "al igual que la crítica, la traducción es, en sí misma, valorización o consagración [...] El reconocimiento crítico y la traducción son, por consiguiente, armas en la lucha por y para el capital literario" (39). Estas instancias, sin duda, delinean el valor literario de acuerdo con los intereses de las instituciones, grupos, revistas, cenáculos, etcétera, que los arropan. ${ }^{1}$

${ }^{1} \mathrm{Al}$ respecto, difiero de Casanova, para quien "esos grandes intermediarios son [...] los más ingenuamente investidos de la representación más pura, más deshistorizada, 
Además de favorecer la configuración del capital literario, ${ }^{2}$ la crítica encarna un momento esencial, el último, del proceso de producción de la obra literaria (Bourdieu: 258); ${ }^{3}$ por su parte, Owen no solo funge de intermediario en esta "historia de las rivalidades" como crítico, sino que forma parte de otro grupo de mediadores, los traductores. Críticos y traductores tienen la responsabilidad de consagrar a unos autores y no a otros, unas literaturas y no otras en el campo literario. Owen, de esta manera, se sitúa junto a una pléyade de escritores hispanoamericanos con una carrera similar, de creadores (poetas, narradores, ensayistas o todo eso) e intermediarios (críticos y traductores), para bien de las letras continentales: César Moro, Jorge Luis Borges, José Bianco, Julio Cortázar, Adolfo Bioy Casares, Octavio Paz, por citar a unos cuantos.

Aun cuando en este caso me ciño exclusivamente a las traducciones de Owen, considero que la opinión de Borges sobre la traducción se ajusta a la actualidad y al contexto mexicano: "El arte de traductor es tenido en poco por los años que corren. No lo entendió así la Edad Media y en el siglo Xvi un poeta francés pudo llamar a Chaucer gran traductor (grand translateur), sin que nadie sintiera un desnivel entre el adjetivo y el nombre o sospechara un propósito malicioso" (Borges: 55). En el ámbito hispánico, tan prestigiosa era la traducción durante los Siglos de Oro, por ejemplo, que los poetas se imponían como un reto escribir "a la manera de". Otras veces, cuando el plagio no tenía el prestigio de hoy, traducían pasajes de autores extranjeros y los adoptaban creativamente a su propia obra, verbigracia El crotalón que bebe en las fuentes de Lucano y Ariosto.

\footnotetext{
'desnacionalizada', despolitizada de la literatura, los más firmemente convencidos de la universalidad de las categorías estéticas a través de las cuales se evalúan las obras” (39). Como ejemplo de mi desacuerdo, en el caso mexicano pueden revisarse las colaboraciones críticas y las traducciones en una revista supuestamente vanguardista, Horizonte (1926-1927); se verá que críticos y traductores muestran, ostensivamente, una posición política, nacionalista y bien plantada en la historia inmediata a favor de una ideología en marcha. Otro ejemplo: los futuristas rusos que terminan adhiriéndose a la revolución marxista-leninista.

${ }^{2}$ Dice Casanova sobre los críticos: "La numerosa presencia de grandes intermediarios trasnacionales, de finos letrados y de críticos refinados es, dicho de otra forma, un índice importante de poder literario" (37).

${ }^{3}$ De acuerdo con Bourdieu, "el discurso sobre la obra no es un mero aditivo, destinado a favorecer su aprehensión y su valoración, sino un momento de la producción de la obra, de su sentido y de su valor" (258).
} 
En sentido contrario, en México ha habido poco interés y menos esfuerzo por reunir, o estudiar, las traducciones firmadas por escritores de renombre. Así, el papel de intermediarios privilegiados ha sido obliterado por los prejuicios de la crítica y, con ello, el papel fundamental de introductores de otras literaturas en el ámbito nacional. A mi juicio, las traducciones de un literato pueden muchas veces contribuir a establecer deudas, angustias, antecedentes, intertextualidades con otros escritores, en fin, vías inéditas de análisis. El caso de Owen resulta paradigmático, ya que su inclinación por la traducción de otras lenguas provendría de su temprana formación en el Instituto Científico y Literario de Toluca, donde el inglés y el francés eran asignaturas obligatorias; es más, ahí mismo fue maestro de francés, como antes lo había sido el decadentista Francisco M. de Olaguíbel. Al parecer, por lo que Esperanza Velázquez Bringas y Rafael Heliodoro Valle refieren, Owen practicaba la traducción de forma compulsiva y la combinaba con su producción lírica y narrativa. Véase la extensa lista que aquellos registran en su Índice de escritores, un manjar para Tántalo por su riqueza y su inasequibilidad:

Ha publicado: La llama fría, novela (ediciones de El Universal Ilustrado, México, 1925). Tiene en prensa: Desvelo, poemas, y Novela en forma de nube; y en preparación: Linea, poemas en prosa; Examen de pausas, novela; Fernando Dantin, novela. Traducciones de Lautréamont: VI Canto de Maldoror, novela; de Rimbaud: Iluminaciones, verso y prosa, y Temporada en el infierno, verso y prosa; de Jules Romains: Odas y plegarias, verso; El burgo regenerado, novela, y Donogo Tonka, novela; de Roso di San Secondo: Lazarina entre cuchillos, farsa; de J. C. Barrie: Quality Street, comedia y de Claude Roger Marx: Simili, comedia. Ha colaborado en La Falange (1923), Antena (1924), Sagitario (1926-27), y Ulises (1927), todas de México. Bachiller en Toluca (1922). Catedrático de Lengua y Literatura Francesas en aquel Instituto (1921).

Nació en El Rosario, Sinaloa, México (1904). Hizo sus estudios allá y en Toluca (1915 a 1922). Actualmente es empleado público.

Su dirección: Uruguay 105, México, D. F. (Velázquez y Valle: 216).

Con el tiempo, la vasta obra en proceso y las muchas traducciones anunciadas devienen un motivo para la saudade: ¿dónde naufragaron Fernando Dantin y el resto de Examen de pausas? Desvelo, aparte de los adelantos en Ulises, solo saldría a la luz en 1953. De las traducciones: unas líneas de Lautréamont en Ulises (y no del Canto VI de Maldoror), 
nada de Rimbaud ni de Romains ni de Barrie. De Roger Marx, al parecer, no se tiene mayor noticia de una posible publicación ${ }^{4}$ y solo hasta 1944 apareció la comedia de Roso di San Secondo en El Hijo Pródigo.

Para alimentar esta infructuosa busca de las traducciones perdidas, hay más ejemplos de la función mediadora de Owen en el ámbito periodístico, como lo confirman las múltiples traducciones que publicó como parte de su trabajo de inflador de cables de la United Press en El Tiempo (ca. 1932-1936). Para mostrar la actitud de Owen ante su actividad de traductor de cables, véase cómo en una crónica titulada “¿Qué puede hacerse en este Tiempo?” (El Tiempo, 17/diciembre/1934), amparado por el seudónimo de Max Carón, propone cambios en todos los órdenes del diario colombiano, entre otros:

¿Y cómo en vez de traducir los cables al castellano, Gilberto no los pone en inglés, y funda aquí una escuela de idiomas para los curiosos que quieran saber qué pasó en las Islas Galápagos y cuántos prisioneros cogieron los paraguayos? Yo haría grandes cosas como director de este periódico. Me compraría otro vestido, en primer lugar. Y me tomaría unos tragos. Y le ordenaría a don Fabio que me aumentara el sueldo (ápud García y Cajero: 215).

Meses más tarde, en "Un monosindicato que se adhiere a las huelgas" (El Tiempo, 14/enero/1935), Max Carón incluye un pliego petitorio donde delata y, a la vez, desvirtúa la profesión de su alter ego, la de traductor de cables del inglés y del francés: "Obligación de Gilberto Owen (el señor de la atalaya) de no hacerlo maromear en los cables y de prestarle el sobretodo cada vez que uno quiera presumir en cine" (ápud García y Cajero: 224).

Como jefe de redacción de Estampa. Revista Semanal de Actualidad Gráfica (entre el 26 noviembre de 1938 y el 1 de abril de 1942), seguramente Owen también tuvo que traducir páginas completas para alimentar esta revista con tópicos de interés general: sobre un pintor, un poeta, una fecha memorable, un hecho curioso o extraordinario. Lo lamentable es que si ni a Josefina Procopio, su editora, mencionó las decenas de artículos y crónicas en las emisiones diarias de El Tiempo, con su nombre o con seudónimo, menos referiría los textos que vertió

4 Según Vicente Quirarte (83), no todo se ha perdido, porque Marinela Barrios Otero tiene a su resguardo el mecanuscrito que Owen hizo de Le pelerin, de Vildrac. 
al español, ya del francés, ya del inglés, en la revista de don Fernando Martínez Dorrien.

\section{LAS TRADUCCIONES CONOCIDAS}

\section{Paul Valéry}

Al parecer, hacia 1927-1928 Owen leía fervorosamente a Paul Valéry, como lo demuestra "Poesía-¿Pura?-Plena. Ejemplo y sugestión", donde arremete contra Mallarmé y, de paso, abjura de la teoría poética del autor de El cementerio marino, porque "la poesía pura es rara e improbable, ha dicho Valéry, y solo puede proceder por maravillas excepcionales" (1979: 227). Ante esta quimera, el rosarino opone una "poesía plena", cuya "fórmula estética se integraría por dos cualidades básicas, arbitrariedad y desinterés [...] Poesía plena, equilibrio: palabras nuevas, imágenes e ideas nuevas, $y$, por dentro, presente e invisible, la parte de Dios, el fluido —oh Cocteau ineludible-, la poesía pura" (227-228). ${ }^{5}$

Otra evocación de Valéry aflora en la "Nota autobiográfica" que precede a varios poemas de Owen reproducidos en el suplemento literario de El Tiempo, Lecturas Dominicales (22/enero/1933), donde el mexicano alude a la época en que publicó los textos traducidos de aquél, hacia 1928:

Para la antología que se publicó en Espańa con retratos de Maroto escribí una vez: "Gilberto Owen es un bailarín flaco, modesto y disciplinado"; me asombra ahora la inmodesta exactitud de aquellas notas, al recordar la sutil diferencia que Valéry advierte entre la danza (poesía) y la marcha (prosa). Me ocupa hoy aprender a marchar al paso trabajoso del pueblo, y sólo a veces, por las noches, vuelve a ganarme la liturgia del baile (1979: 197).

La autorreferencia de Owen proviene de la presentación que escribió para la Galería de los poetas nuevos de México [Nueva antología de poetas

5 Termina Owen su alegato con una exhortación a la manera de Carlos Marx: "Vamos, contemporáneos de aquí y de todas partes, vamos libertando a la poesía pura, amigos [...] Vamos, contemporáneos amigos, vamos a intentar una obra sensual purificada, con inteligencia y desinterés". 
mexicanos], a cargo de Gabriel García Maroto, publicada en Madrid en 1928. De esta suerte, en Contemporáneos, núm. 4, de septiembre de 1928, aparecieron los textos que Owen tradujo de Valéry: "Pequeños textos. Comentarios de grabados" ["La madre joven", "El hombre volador", "La cazadora", "La amazona", "El atentado"]. Owen paga, así, una deuda con uno de los poetas más influyentes en la conformación de su propia estética, además de establecer un fructífero diálogo con el más purista de los puristas: el abate Henri Bremond.

\section{Emily Dickinson}

En las páginas centrales del suplemento Lecturas Dominicales (El Tiempo. Bogotá. Núm. 536. 29[28]/abr/1934) aparecieron publicados los "Poemas de Emiliy Dickinson. Versiones a ojo de Gilberto Owen" (6-7); más adelante, se inserta una nota titulada "Emily Dickinson [Datos biográficos]" (12) también firmada por Owen. Ninguno de los dos textos se halla compilado ni en Poesía y prosa ni en Obras; en Gilberto Owen en El Tiempo de Bogotá, prosas recuperadas (1933-1935), sí se recupera la prosa sobre Dickinson (cfr. García y Cajero: 57-59). Lo primero que salta a la vista en el esbozo biográfico escrito por Owen es la noticia de que había traducido doscientos poemas de Dickinson. Por este palimpsesto, puede afirmarse que la función mediadora del rosarino resulta opacada por sí mismo: no únicamente sacrifica su labor de traductor, sino la de periodista, en aras de una imagen de poeta, narrador y crítico, acaso más prestigiosa desde su escala personal de valores.

Si bien se trata de una sintética biografía de Dickinson para presentar las traducciones de sus "traducciones a ojo" y para instruir al público de El Tiempo, Owen aprovecha para dejar rastro de su propia vida cuando recuerda su viaje a Amherst, la ciudad natal de Emily Dickinson, con el fin de indagar sobre la poetisa: "recogíamos detalles demasiado pueriles para andar en los libros; de su padre (aquel doctor Dickinson que un día tocaba la campana de incendios del pueblo para que los habitantes se llegasen a admirar una puesta de sol) [...] Luego aprendimos cuán superficial y vana nuestra búsqueda, si los datos reales de su biografía estaban, vivos y ardorosos, en sus poemas y en su epistolario" (1934b: 12). 
También debe subrayarse la escueta explicación oweniana sobre las traducciones publicadas, incluida una seria reflexión sobre el papel del traductor de poesía, cuya función consistiría en acercarse tanto como sea posible al espíritu del texto original. Dice Owen en una modesta tercera persona y en una ya de por sí modesta explicación: "Los ha llamado 'traducciones a ojo', para expresar la actitud de improvisación y descuido que, cuidadosa y trabajosamente, ha tenido que adoptar en esta obra, eludiendo con cautela el léxico solemne y la retórica convencional que Emily Dickinson rechazaba y violaba inexorablemente". Ciertamente, Owen no intenta traducciones literales de los poemas de Dickinson; estudia los motivos principales y con ellos presenta versiones de una poesía que rehúye la sintaxis común y la hermenéutica facilona.

Por su riqueza conceptual y su claridad expositiva, resulta más que pertinente reproducir el texto completo sobre Dickinson, ya que se inscribe entre tantos "clásicos" owenianos:

\section{Emily Dickinson (datos biográficos)}

Cuando Conrad Aiken, en nombre de su generación americana, afirmaba hallar en la poesía de Emily Dickinson "la más fina, quizá, que mujer alguna de habla inglesa haya escrito", solo merecía reproche de Martín Armstrong y los poetas británicos, por la timidez de su quizá. Y de nosotros también, ahora y en los días que descubríamos y dibujábamos amorosamente los litorales de su mundo (en el estío indiano de aquella peregrinación a Amherst que cuenta decisivamente en nuestra vida), intentando seguirla en su mínima odisea de "Balboa de su casa y su jardín". Mundo extraño e inesperado, que nos desconcertaba con sus líneas pueriles y simples, sus formas irresueltas, sus colores elementales, entre las cuatro tapias del convento familiar, sobre el que reconocía áreas de sobrenatural a las cuales lanzaba la blasfemia íntegra de Blake.

En aquel viaje, que llenaba de dificultades la vecindad del ex presidente Pero Grullo — todos sabían mejor la casa de Coolidge que la de Emily - recogíamos detalles demasiado pueriles para andar en los libros; de su padre (aquel doctor Dickinson que un día tocaba la campana de incendios del pueblo para que los habitantes se llegasen a admirar una puesta de sol), del amante, largo y desgarbado, junto al cual se vería ella como Ana al lado de Lindberg, de Sue y de la otra hermana inasible. Luego aprendimos cuán superficial y vana nuestra búsqueda, si los datos 
reales de su biografía estaban, vivos y ardorosos, en sus poemas y en su epistolario.

Bastan estos detalles exactos: Emily Dickinson nació en Amherst el 10 de diciembre de 1830; murió en la misma casa, de la que saliera en la breve temporada que agota su experiencia de amor, el 16 de mayo de 1886. Escribió casi 800 poemas, que no destinaba al público, y que por ello se resienten algunas veces de inconclusión. Monja laica, esquiva al mundo física y espiritualmente, cerraba su mundo de poesía a todos los que la rodeaban, y solo pudieron sus amigos decidirla a publicar, durante su vida, dos o tres poemas en el periódico local. Pasó su vida leyendo los "boletines de eternidad", que a diario la visitaban.

Pocos años después de su muerte se publicaron sus Poemas (1890, 92 y 96), en tres series, y El mastín solitario (1914). Pero tocaba a la generación de 1924 el reconocimiento total, que una crítica severa erige al frente de la moderna poesía inglesa.

Emily Dickinson no es casi conocida en español; Juan Ramón Jiménez tradujo un poema suyo, en el viaje del poeta recién casado a Nueva Inglaterra; Gilberto Owen ha traducido una selección de 200 de sus poemas, de los cuales se toman los que aparecen en esta página, aún inéditos.

Los ha llamado "traducciones a ojo", para expresar la actitud de improvisación y descuido que, cuidadosa y trabajosamente, ha tenido que adoptar en esta obra, eludiendo con cautela el léxico solemne y la retórica convencional que Emily Dickinson rechazaba y violaba inexorablemente, sin entender de la poesía sino el temblor inexplicable, inaudible e invisible que revela este párrafo de una de sus cartas: "Si al leer un libro siento que todo el cuerpo se me hiela, en forma tal que ningún incendio podría calentármelo, yo sé bien que es poesía. Si siento al leerlo, en sensación solamente física, como si me arrancasen el cráneo, yo sé bien que es poesía. Son ésas las únicas maneras que tengo yo de saberlo”.

Pasmado ante este resucitar suyo magnífico en otro siglo, atravesando, tan buen buzo como Stendhal, la tempestad en una lágrima del ochocientos, tan pura su voz en la distancia, su traductor al español compuso una larga elegía que arrancaba así:

Toda la noche bailáramos un viento que pensaba.

Pongamos la lámpara bajo el almud sepamos la medida exacta de su luz que si en tanto a ninguno alumbra ya guiará a los pródigos de 2030 en su busca.

Bogotá, abril de 1934. 
Agnes Smedley ${ }^{6}$

Respecto de la traducción de China en armas, el testimonio de Cecilia Victoria, la hija mayor de Gilberto Owen, reproducido por Quirarte resulta hasta cierto punto cuestionable: "No será sino hasta 1943 que los Owen Salazar ocupen nueva casa, en la calle 70 con la $7^{\mathrm{a}}$. Su hija Cecilia Victoria lo recuerda en la mansarda de esa mansión, escribiendo a máquina, con dos dedos y a gran velocidad, la traducción de China en armas" (Quirarte: 107). Owen, sin embargo, para 1943 se halla en México en lo que podría denominarse la vuelta del hijo pródigo. Ahí radica entre 1942 y 1944, y colabora ampliamente con Letras de México y El Hijo Pródigo.

Páginas después, Quirarte amplía su noticia sobre la traducción de Smedley: "Un adelanto de la novela China en armas, de Agnes Smedley, bajo el título 'El automóvil número 1469', aparece en El Hijo Pródigo del 10 de enero, libro que habrá de aparecer el año siguiente en Editorial Nuevo Mundo" (124). Dos aclaraciones: este adelanto se encuentra en el número 10 de El Hijo Pródigo, del 15 de enero de 1944, y China en armas se publicó no el año siguiente, sino hacia finales de abril del mismo 1944. En la sección "Notas. Se Recomienda" de la misma emisión donde aparece este adelanto, se dice: "'El automóvil número 1496' fragmento del libro China en armas (Battle Hymn of China) de la inquieta escritora norteamericana Agnes Smedley, que publicará próximamente la Editorial Nuevo Mundo. La traducción es de Gilberto Owen" (60).

Respecto de la publicación de China en armas hay varios anuncios de venta en Letras de México: en el primero de ellos, se dice que se trata del "mejor libro sobre la China de hoy" con el crédito respectivo del traductor; su costo era de diez pesos. Con la reseńa titulada "Un canto a China”, Isaac Rojas Rosillo dio la bienvenida al libro de Smedley en

6 Agnes Smedley. Nació el 23 de febrero de 1822 en Missouri, Estados Unidos, y murió el 6 de mayo de 1950, en Oxford, Inglaterra. Fue periodista y novelista, su novela autobiográfica Hija de la tierra (1929), su obra más conocida, narra sus andanzas en la revolución China. Otras de sus novelas son: Chinese Destinies (1933), China Red Army (1934), China Fights Back. An American Woman With the Eight Route Army (1938), Battle Hymn of China (China en armas, 1943) y The Great Road: The Life and Times of Chu Teh (1956) (Información tomada del libro The Lives of Agnes Smedley, de Ruth Price. New York, Oxford University Press, 2005). 
el número 17 de Letras de México y, de paso, hizo énfasis en el trabajo de Owen: "se ve que el traductor puso amor en una obra de mérito literario y de importante contenido social, sin que sea mengua para esta apreciación el error en que incurre Agnes al hablar en primera persona y dar a conocer sus propias experiencias" (6).

Además, aunque no se anuncia China en armas en El Hijo Pródigo, esta revista publica una reseña firmada por Antonio Sánchez Barbudo, exiliado español. Como muestra del tono de la recensión, solo habría que reproducir el encomiástico párrafo inicial:

De todos los libros de información sobre la guerra, ninguno quizás más necesario ni más interesante que el que Agnes Smedley ha escrito sobre China. A China la olvidamos muchos, no sólo los culpables de sus desgracias, porque desconocemos lo que allí sucede. China en armas tiende a recorrer este velo, a mostrarnos lo que en verdad pasa ahí (57).

\section{Rosso di San Secondo}

En su ya referida "Nota autobiográfica" de 1933, Owen menciona la curiosa anécdota sobre la traducción de Lazarina entre cuchillos: "He traducido poemas, novelas, comedias, ensayos, no sé qué no, del inglés y del francés. Como nunca he tomado en serio el italiano sólo he traducido del español al español una farsa de Rosso de San Secondo, traducida del italiano por Agustín Lazo, pintor" (1979: 198). El crédito de El Hijo Pródigo atribuye la traducción a Owen y Lazo, si bien aquél

7 Pier Maria Rosso di San Secondo nació en Caltanissetta, el 30 de noviembre de 1887 y murió en Lido di Camaiore, el 22 de noviembre de 1956. Fue dramaturgo y periodista, su poética se caracteriza por su lirismo y por una visión pesimista del hombre y de la sociedad. Sus personajes están estigmatizados por la soledad y padecen una lucha interna entre la razón y la pasión. Esta lucha está simbolizada por los enfrentamientos de la mentalidad norteña, racionalista, concreta y gris, y la sensibilidad del sur, pasional y violenta. Las obras teatrales más famosas de Di San Secondo son $L a$ sirena ricanta (1908), Marionette, che pasione (1917), La bella addormentata (1919), L'ospite desiderato (1921), Tra vestiti che ballano (1927), Il ratto di Proserpina (1954) y Una cosa di carne. Il delirio dell'oste Bassà (1954). También publicó dos novelas: Ponentino (1916) y La fuga (1917) (Información tomada de Giuseppe Petronio. Historia de la literatura italiana. Traducción de Manuel Carrera y María de las Nieves Muñiz. Madrid: Cátedra, 1990). 
en 1928 la había puesto entre la nómina de sus taducciones (véase arriba). Al mismo tiempo, cabe resaltar el jugueteo de quien años antes ya había referido esta labor de traductor monolingüe en la nota "Sandino y Goliat": "Pensamos todo esto al abrirnos paso, trabajosamente, por entre la prosa tropical y silvestre del señor G. Alemán Bolaños, cuyo libro sobre Sandino, indudablemente rico en datos sobre la vida del héroe, acabamos de traducir de su español al nuestro" (ápud García y Cajero: 48).

\section{Roger Caillois ${ }^{8}$}

Owen tradujo, también, "Actualidad de las sectas", de Roger Caillois, en El Hijo Pródigo (4 [14]. 15/mayo/1944: 89-92). Al respecto hay una curiosa anécdota: hasta donde he investigado, la versión en español antecede a la francesa en la prensa. No es sino hasta el número 14 de Lettres Françaises, de octubre de 1944, cuando Caillois publica su artículo en francés. Ahí no acaba todo. Es más curioso que el texto traducido por Owen haya pasado a ser la introducción de Ensayo sobre el espiritu de las sectas, publicado por El Colegio de México en 1945. En este caso, el crédito de la traducción es de Julián Calvo; sin embargo, ¡oh, sorpresa!, cuando cotejé la traducción de Owen con la de Calvo, me percaté de que coincidían letra por letra. Además, se confirma que se trata de la traducción de un texto inédito de Caillois. Para acentuar la identidad de una y otra traducción, se nota que ni siquiera se corrigió un anacoluto de la versión oweniana, ahora atribuida a Calvo: "Pero algunos de nosotros, llenos de fervor, no se resignaban de buena gana a interpretar solamente. Estaban impacientes de obrar por su cuenta”.

${ }^{8}$ Roger Caillois nació en Reims el 3 de marzo de 1913 y murió el 21 de diciembre de 1978 en Kremlin-Bicêtre. Reconocido sociólogo de la religión y crítico relacionado con el surrealismo. En 1933 ingresó a la École Pratique des Hautes Études, donde estudió sociología de la religión con Marcel Mauss y mitología comparada con George Dumézil. En diciembre de 1934 abandonó el surrealismo, desencantado por la falta de rigor científico y la naturaleza meramente literaria de sus experimentos. Durante la segunda Guerra Mundial se refugió en Argentina, regresó a Francia en 1945. Sus obras más conocidas son: El mito y el hombre (1938), El hombre y lo sagrado (1939) y Los juegos y los hombres: la máscara y el vértigo (1958). (Información tomada del libro The Edge of Surrealism. A Roger Caillois Reader. Editado por Claudine Frank. North Caroline: Duke University Press, 2003.) 
¿Calvo se apropió la traducción de Owen o éste sugirió que aquél la firmara para que no se viera el nepotismo del entonces director de El Colegio de México, su amigo y editor, don Alfonso Reyes? En cualquier caso, he constatado que la misma versión firmada por Owen en El Hijo Pródigo se reprodujo en Fisiología de Leviatán (1946), de Caillois, que incluye el Ensayo sobre el espiritu de las sectas, con traducción de Calvo y Jordana. ${ }^{9}$

\section{James Branch Cabell ${ }^{10}$}

Ahora, una traducción que Josefina Procopio se habría negado a incluir en Poesía y prosa; por fortuna, cayó en manos de un amigo leal de Owen, José Rojas Garcidueñas, en las circunstancias que él mismo relata en la "Advertencia" a la traducción calificada de "inconclusa, incompleta, sin revisión final":

Es muy explicable y justificado que Josephine Procopio no haya querido incluirlos en el tomo de Poesía y prosa. En primer lugar, esas cuartillas

9 El libro El exilio español en México 1939-1982. FCE/Salvat, consigna que Julián Calvo Blanco nació en Murcia el $1^{\circ}$ de febrero de 1909. Teniente auditor del Cuerpo Jurídico Militar; magistrado del Tribunal Central de Espionaje y Alta Traición de España; llegó a México en 1940. Trabajó en el Fondo de Cultura Económica, editorial en la que realizó numerosas traducciones, lo mismo para El Colegio de México. Fue secretario de la revista Litoral. Joaquín Díez-Canedo recuerda que en 1944 trabajaba en el Fondo de Cultura Económica "Julián Calvo, gran amigo de Jorge Guillén (fue quien cuidó la edición mexicana de Cántico) [...] Julián Calvo murió hace poco [esto lo dijo Díez-Canedo en el año 1994]. Era una excelente persona, muy espléndido. Además era gran masón de Espańa, masón de carrera. [...] Fue secretario de Litoral durante su etapa mexicana. Por otra parte, fue muy amigo de Emilio Prados y también de Guillén. Rte: Joaquín Mortiz. Edición Homenaje. Guadalajara, Universidad de Guadalajara, 1994: 89.

${ }^{10}$ James Branch Cabell nació el 14 de abril de 1879 en Richmond, Virginia, y murió el 5 de mayo de 1958, en la misma ciudad donde nació. Es considerado como uno de los grandes ironistas de la literatura que retrata la aristocracia norteamericana, con un estilo "florido", premonición de lo que hará Francis Scott Fitzgerald. Curiosamente, The Music from Behind the Moon (1926) es una obra que escapa a la temática social de Cabell en el que incursiona en el poema en prosa onírico y fantástico en el que se narra el destino fatal de dos amantes, Ettarre y Madoc. Ella será condenada a vivir en la tierra baldía de la luna por 725 años y él, Madoc, será "insertado después del séptimo dígito del punto decimal”. Información tomada del libro James Branch Cabell, de Carl Van Doren. New York, Wildside Press, 2008. 
son una primera versión no corregida; solamente las dos primeras páginas fueron revisadas y en ellas hay tantas alteraciones y retoques [...] que es de suponer que Gilberto habría hecho otro tanto con las restantes. Pero, años más tarde, Fina Procopio me obsequió esas cuartillas y me autorizó a publicarlas, con las explicaciones del caso, como ahora lo hago, como un documento que contiene la última tarea literaria, inconclusa, de Gilberto Owen (Rojas Garcidueñas: 80).

El fragmento traducido proviene de James Branch Cabell, "The music from behind the Moon", primera parte de The Witch-Woman. A Trilogy About Her, Farrar, Strauss \& Young, 1948. Rojas Garcidueñas supone que esta traducción pudo ser la última "tarea literaria" de Owen. No necesariamente: también colaboraba con Fina Procopio en la preparación de Poesía y prosa, así como en el proyecto de un libro anunciado del que no se conoce un solo verso. Así lo refiere Owen al mismo Rojas Garcidueñas: "Acaso les lleve algo más que ese poema viejo que con tan inteligente cariño ha presentado José. Puede ser que sea mi último libro. Se va a llamar, con un título que nadie ha empleado en este siglo, La danza de la muerte" (1979: 294). El "poema viejo" a que alude Owen pueder ser "Libro de Ruth" que, con "Madrigal por Medusa", se reprodujo en América. Revista Antológica (Núm. 50. Diciembre/1950: 94-100) por mediación de Rojas Garcidueñas.

\section{LAS TRADUCCIONES PERDIDAS}

Entre las traducciones perdidas que podrían estar soterradas en algún archivo personal, por ejemplo en el de los Goros, José y Celestino, se encuentran las que enumera una nota de la redacción de la revista $E l$ Espectador, dirigida por Humberto Rivas: "San Secondo: Lazarina entre cuchillos. Trad. de Gilberto Owen", "Roger Marx: Simili. Trad. de Gilberto Owen" y "Charles Vildrac: El peregrino. Trad. de Gilberto Owen" (ápud Magaña: 83 en "Documentos"). El anónimo redactor, nuevamente, atribuye solo a Owen la traducción de San Secondo.

También pueden considerarse extraviadas las traducciones que Owen preparaba para una antología de poetas norteamericanos jóvenes a cargo de Alfonso Reyes, originalmente para los Cuadernos del Plata, luego sustituida por Linea. Sobre esta empresa, Owen pregunta a Villaurrutia 
(29/noviembre/1929): “¿Qué traducciones le has enviado a Reyes para su antología? Yo estoy traduciendo a los cuatro o cinco que no han publicado libro. De dos de ellos estoy seguro, pues valen, de los otros todavía no sé" (1979: 268). Y luego, Owen insiste con Alfonso Reyes (18/ diciembre/1928), aunque se desconoce la respuesta del corresponsal:

Genaro me escribe de la antología de jóvenes yanquis, en traducciones de jóvenes mexicanos, que está usted formando, y de su deseo de mi colaboración. Querría enviarle con esta carta versiones hechas en Méx., pero no hay allá quien pudiera encontrarlas entre mis papeles, y las hechas aquí, descuidadas al margen de libros leídos de prisa, necesitan una revisión que voy a emprender en cuanto acabe unos inventarios a que me han condenado. Le enviaré todo lo que pueda, pues ignoro si usted señaló simpatías y diferencias a cada uno, y temo que lo que yo le mande se cruce con tareas impuestas a mis compañeros, a quienes he perdido de vista desde hace ocho meses. 15 días me llevará enviarle eso (¿Sandburg, Kreymborg, W. Carlos Williams, Witter Byner, Countee Cullen?). Quiere decirme luego, luego, si le interesa interesarme en algún poeta de aquí especialmente? Dígame un poco más preciso que el párrafo de Genaro, que me voy a quedar esperando sus órdenes (272-273).

Imposible saber el destino de estas traducciones aún sin revisar. Otro texto que también puede considerarse perdido es el que anuncia a Reyes desde Bogotá (14/marzo/1933): "traduzco el Jeremías de Zweig para no salirme a la calle a gritar mi protesta contra esta guerra incalificada" (277). Finalmente, unas traducciones que Owen menciona en un artículo de homenaje póstumo sobre Edwin Arlington Robinson (7/ abril/1935): "Ahora no voy a escribir de Edwin Arlington Robinson; andan entre mis papeles muchas versiones de sus poemas; se mueren entre mis papeles muchas notas que entonces eran imágenes vivas y vívidas; yo le pido, ahora que sé de pronto qué grande amigo mío era, el respiro del orden para ordenarme sus recuerdos" (ápud García y Cajero: 97). Hasta aquí los lamentos y en seguida unos felices hallazgos.

\section{TRADUCCIONES RESCATADAS}

Además de las traducciones más o menos conocidas de Owen, casi todas insertas en revistas, quiero mencionar otras tres totalmente desco- 
nocidas en su bibliografía. La primera traducción publicada por Owen no sería la de los poemas de Paul Valéry, en Contemporáneos, sino otra que se halla al final de una colaboración en Ulises hasta hace unos meses olvidada. Me refiero al fragmento del prefacio de un poemario que, quizá, Lautréamont nunca escribió. En la sección "El Curioso Impertinente", se encuentra este ejercicio de traducción después del apartado "Margarita de niebla y Benjamín Jarnés", con el titulillo "Lautréamont". Al parecer, el traductor también tenía entre manos un avance del VI de Los cantos de Maldoror; se conforma, sin embargo, con ofrecer las líneas del paratexto sin texto, en los términos siguientes:

Enterrado en los anaqueles herméticos de los bibliófilos —que, si no los hubiera tan queridos amigos, iban a recordarnos en símil ofensivamente exacto al perro del hortelano- dormía este Lautréamont, de quien todos, desde el cincuentenario de su suicidio, vienen declarándose más o menos deudores. Philippe Dada (né Soupault) le ha despertado y ha emprendido la tarea, que repugna tal vez con las intenciones minoristas de Ducasse, de hacerle familiar al gran público, reuniendo en un volumen toda la obra, corta y fecunda, de una vida como ella que apenas alcanzó los cuatro lustros, obra cuya vibración, en una especie de eco invertido que del silencio del fin de siglo viniera, concentrándose, al sonido original que hasta ahora oímos cabal, persiste en influencias decisivas sobre la poesía y la prosa contemporáneas. Todo ha cabido en el pulcro volumen reciente, poesía, crítica, novela. —Sí, novela; alguna vez pondremos esta palabra al pie de la traducción que preparamos del VI Canto de Maldoror, y ya hemos aumentado el catálogo de libros del Manual del perfecto aventurero, con este nombre: Isidore Ducasse-. De su prefacio a versos que nunca fueron encontrados, en los que corregía "en el sentido de la esperanza", la gran voz del pelícano que en su hora triunfaba, entresacamos estas agudas, ¿nuestras?, arbitrarias afirmaciones (cfr. Cajero: 83-84).

Luego de las iniciales de su nombre, G. O., Owen reproduce el fragmento traducido. Por esta afición, no resulta extraño que cuando parte hacia Nueva York, a mediados de 1928, Owen lleve consigo las Obras completas de Lautréamont. ${ }^{11}$ Este, indudablemente, influyó en la con-

11 Owen describe a Villaurrutia el cuarto que habita en Nueva York, incluido un librero con las Obras completas de Joseph Conrad, Obras completas de Lautréamont, 
fección de los poemas de Línea, pues su obra "persiste en influencias decisivas sobre la poesía y la prosa contemporáneas".

Las otras dos traducciones completamente desconocidas en México son: "Lázaro Cárdenas, un indio asceta" (19/enero/1935), de Lestrois Parish, y "Las sorprendentes aventuras del Barón de Munchausen" (7/ agosto/1935), ambas aparecidas en las planas de El Tiempo. Las presento como aporte a las obras incompletas de Owen, así como una muestra más de la escritura poligráfica y de la función mediadora de los Contemporáneos, en general, y del autor de Perseo vencido, en particular.

Owen creció durante la efervescencia de la Revolución, por lo que su fascinación por personajes como Álvaro Obregón o, ya más tardíamente por Lázaro Cárdenas y su gestión socialista, no resulta gratuita; al contrario, representan una suerte de coincidencia con su propia historia: con el primero trabajó como secretario hacia 1923 y con el segundo coincidió en el ideario socialista que Owen practicó, en muy diversas modalidades, en Sudamérica al lado de Haya de la Torre, Luis Alberto Sánchez, Benjamín Carrión y, acaso, de Pablo Palacio y Martín Adán.

Owen, a su vez, estaba orgulloso de formar parte de una generación heredera de la Revolución. A su juicio, hacia 1920 en México todo estaba por inventarse y los jóvenes tenían el compromiso de aportar cuanto estuviera en sus manos, como una contribución altruista y entusiasta que los detractores de Contemporáneos apenas si valoraron; antes bien, en consonancia con los nacionalistas de aquel entonces, y de ahora, no pasan de ser considerados extranjerizantes y burgueses. En "Poesía y revolución", Owen pasa lista al ejército reconstructor de la nación devastada por "el fecundo huracán": "Unos éramos economistas, otros éramos campesinos, otros éramos ingenieros, otros éramos artistas. Todos éramos original, esencialmente, revolucionarios" (1). La cicatriz de la Revolución caló muy hondo en el rosarino, pues hasta la poesía que todos calificaron de reaccionaria nació de esta ineludible vocación. De esta suerte, en las Lecturas Dominicales del 14 de septiembre de 1935, publica "Dedicatoria" con la intención de celebrar el $125^{\circ}$ aniversario de la Independencia de México. En otra curiosa intratextualidad oweniana, "Dedicatoria" comienza con un resumen de "Poesía y revolu-

Obras completas de Poe, una gramática inglesa, un diccionario inglés-español, etc. (cfr. 1979: 261). 
ción" para refrendar unas ideas y un espíritu revolucionario vigentes, y aun más arraigados, durante la travesía sudamericana de Owen:

He entregado — dice— ya a estas mismas páginas el relato, tan desnudo de sentimientos como me fue posible [...] Entonces intenté también mostrar a los lectores de El Tiempo cuán injusto y ligero el cargo de evasión que se hacía a la generación de poetas y escritores que nació a la vida mexicana en aquellos días; qué fidelidad íntima había en ellos a la revolución (1979: 234).

Esta conciencia, acaso, lo llevó a practicar una ética dedicada a causas nobles y justas: lo entusiasma la inminente Independencia de Filipinas, el triunfo de Sandino en Nicaragua, la lucha aprista contra los regímenes autoritarios del Perú, la empresa socialista en Ecuador, acordes con una sui géneris visión revolucionaria. Todo esto viene a colación, porque Owen tiene la encomienda de felicitar en esta fecha a Palma Guillén, ministro plenipotenciario de México en Colombia, al pueblo de México y al "jefe actual de la Revolución Mexicana, general Lázaro Cárdenas” (235). Sin duda, Owen sentía una fuerte simpatía por Cárdenas, pues en la sección de la United Press, en El Tiempo, a menudo seleccionaba noticas relacionadas con la gestión cardenista, verbigracia: la asonada de Garrido Canabal, la salida y la vuelta de Calles, el levantamiento de Cedillo. La deferencia por el gobierno socialista de Cárdenas permitía establecer un doble lazo emotivo con Michoacán: su madre, de ascendencia india, provenía de ese estado. ${ }^{12}$ Asimismo, en el aspecto ideológico, la traducción de "Lázaro Cárdenas, un indio asceta" cumplía dos funciones esenciales en la cosmovisión oweniana del momento: en primera instancia, puede tomarse como un gesto más de admiración por el jefe en turno de la Revolución mexicana y, en segunda, como un mensaje más para los revolucionarios del Continente. ${ }^{13}$

12 "Mi madre era mexicana, con más de indio que de español, y a su padre le debo mi aspecto físico, mi falta de sentido de la propiedad y mis aptitudes para lo inútil, tan laboriosa y vanamente combatidas" (197).

13 Owen se consideraba un mensaje que, en su vida trashumante, iba de mano en mano entre sus amigos, como lo expresa en "Punto de gracia": "Señal de bote en bote, sin casi nada de personal en el mensaje, sin más que unos ojos que se me iban colmando de paisajes con rostros, sin más que una voz reacia a la oratoria. Desde el norte de Waldo Frank y mis amigos de la New School of Social Research quería caerme hasta el Sur de Victoria Ocampo; me tomaban entre sus manos y me moldeaban los de mi 
A la segunda traducción, "Las sorprendentes aventuras del Barón de Munchausen", dedicada a un público infantil, llegué por el anuncio previo a la edición especial que El Tiempo preparó, el 7 de agosto de 1935, para celebrar "el ensanche de sus talleres". Así aparece reseñada la sección del suplemento dedicada a los lectores infantiles del diario bogotano:

\section{EL TIEMPO PARA lOS NIÑOS}

En la edición extraordinaria que publicará El Tiempo, con ocasión del ensanche de sus talleres, el 7 de agosto, se dedicará una sección especial para los niños, que traerá el siguiente contenido:

"El cuento del Padre Almansa", contado por Germán Arciniegas, con dibujos de Alberto Arango.

"Las sorprendentes aventuras del Barón de Munchausen", deliciosamente narradas en forma de anécdotas. Traducción hecha por Gilberto Owen y dibujos de Alberto Arango.

"El Reyecito", historieta en dibujos de O. Soglow, que se considera universalmente como uno de los humoristas mejores, y cuya colaboración se ha contratado especialmente para El Tiempo.

"El renacuajo paseador", la fábula de Pombo, ilustrada íntegramente en doce cuadros por Alberto Arango.

"El Centinela", por O. Soglow.

Esperamos que los pequeños lectores de El Tiempo habrán de regocijarse con la sección que les hemos preparado con cuidadoso esmero (5).

Se dice, además, que las aventuras atribuidas a Karl Friedrich Hieronymus, barón de Münchausen (1720-1797), están "deliciosamente narradas en forma de anécdotas"; sin embargo, el lector puede constatar que, aun cuando se esfuerce, Owen no abandona su estilo: a veces retorcido, otras más plagado de incisos y explicaciones.

\section{UNA POLÉMICA ENTRE TRADUCTORES}

Probablemente, mientras traducía China en armas, Owen leyó y reseñó la traducción de El diablo en el cuerpo de Raymond Radiguet, hecha por Ángel Samblancat. Aun cuando aquél se dedica a perorar sobre la vida y

generación, Haya de la Torre o Lombardo Toledano, Benjamín Carrión o Combariza, Luis Alberto Sánchez o Arciniegas o Lleras Camargo" (ápud García y Cajero: 56). 
la obra de Radiguet, a partir de los testimonios de Cocteau, al final de la reseña hay una serie de reparos contra la traducción de Ángel Samblancat que desatará una breve, pero significativa, polémica desconocida:

La obra ha sido traducida pésimamente al español por una persona que, probablemente, sabe muy bien su catalán, y que ha tratado de hacer superfluas adiciones a nuestro idioma con palabras tales como estrafalariedad, estuporoso, estrampillado [sic], cuestionar por preguntar, parientes por padres, y a copia de en vez de a fuerza de (1944: 120).

Esta valoración trajo como consecuencia la irónica, y muy airada, respuesta del "ofendido" traductor de Radiguet. Owen, acaso, se hallaba preparando su vuelta a Colombia y pudo apenas enterarse de la carta que Samblancat envió a Barreda, provocadora desde la misma fecha, "a 18 Floreal de 1944". Aunque parezca muy extensa, reproduzco íntegramente la misiva aparecida bajo el rótulo "Una carta de traductor", pues si bien Samblancat la envía al "Sr. Director de El Hijo Pródigo", también entabla un diálogo indirecto con otro traductor experimentado:

En la edición del mes en curso, de la revista literaria que V. tan marineramente pilotea o patrona, se inserta una recensión del picante rapport erótico de Raymond Radiguet El diablo en el cuerpo, recientemente editado por Costa-Amic, en la que se estampa textualmente lo que en seguida colaciono: "La obra ha sido pésimamente traducida al español por una persona que, probablemente, sabe muy bien su catalán, y que ha tratado de hacer superfluas adiciones a nuestro idioma con palabras tales como estrafalariedad, estuporoso, entrampillado - el desuellacaras de esta solfa, además de tirar patas arriba mi apellido, despelleja ese vocablo también-; cuestionar por preguntar, parientes por padres, y a copia de en vez de a fuerza de".

El trasladador en "román paladino" de la drolática historiúncula de Radiguet es el escritor español, que hoy comparece debidamente convocado aquí, y con treinta ańos de gloriosa milicia a cuestas; $y$ el firmante de la infumable arbitrariedad traída a cuento, es mi desconocido seńor y acre Aristarco don Gilberto Owen.

Y bien; al zoilo sin tacha y purista inconsútil que nos ocupa, el fustigado inopinadamente por él le ha decir — con su venia, por descontado, seńor Director- lo que a continación pongo en línea.

El autor de la versión tan maltrecha por el señor Owen sabe muy bien —no probablemente, sino con absoluta certitud— su catalán y su 
castellano y su francés y su latín; y hasta un poquito también, su griego y su inglés y su alemán.

Conoce la cervantina habla tan pasablemente, por lo menos, como el señor Owen su escocés; y sus clásicos los tiene bastante más aireados que el caballero susodicho, quien si cerniera un poco más su romanus sermo, no tildaría de pésima una traducción por el mero negro de haba — no aduce otras ilustraciones; ya se explicará, si quiere - de ver injertados en ella cuatro o cinco latinismos, que, sobre estar más sobados que bota de arriero, pueden llevar a los escudos su limpia sangre patricia y el certificado prenupcial de su casta de prócer; y no recusaría y reprobaría irresponsablemente el popularísimo entrampillar, trillado en todas las eras y ruedos de Castilla, y que en la montura en que se le engastó, es nada menos que toda una perla engarzada en oro.

Aunque he dejado escapar de mi aljaba el tópico manido de la cervantina habla, no se entiende que con ello quiera decir que el castellano de hoy le pertenece más al autor del Quijote que a mí. Nuestra época es la de la total y totalitaria quiebra de todos los propietarios de derecho divino. Los idiomas, como la tierra y como la mujer, son de quienes los aman y los cultivan, no de quien presume con ellos. Por tanto, no consentiremos que se haga un coto de caza manchego del castellano; y menos, una eutrapelia anacrónica, behetría gótica señorial o quirital de coqueteos y de snobs; $y$, naturalmente, mucho menos, una raqueta en manos de seńoritos memos natos. El castellano es un útil laborioso y labriego de toda la comunidad hispanogarrulante y cogitante. Y si a México le reconocemos el derecho de hablar nuestra lengua como se hablaba el griego en Cilicia — por mi parte, enchanté- y de taracearlo, alicatarlo y nielarlo de hórridos y carnavalescos gringuismos, ha de ser eso sin mengua del fuego que celosamente reivindicamos nosostros, de rehelenizarlo, relatinizarlo, refundirlo si se tercia, y, por supuesto, bañarlo y empaparlo de plebe.

De superfluidades, superfluencias, rapiñas, rebañaduras y acarreos aluviales mutuos, viven las humaniores litterae de todas las latitudes. A los veinticuatro modos de llamar pepónida al que habla alegremente y con reprensible frivolidad de lo que no entiende, y de adjetivar otros especímenes de nescencia, de que disponemos en mi pueblo, han tenido los argentinos la sorna de ofrecernos todavía el presente de otario. Por mí, que ruede la bola. Y el que tenga algo que decir, que no se lo guarde en el buche. De burdas superfetaciones y adherencias crustáceas de damnable dirección, agregadas innecesariamente al pentagrama de la redundancia y de la sinonimia, han surgido exquisitas flores verbales. Mientras mi ingenio y mi buen humor alienten, no pienso yo dimitir 
mi derecho a acudir al acervo suburbical y a toda la Babel de las jergas, a cargar pedruscos con que lapidar la inaprensión lardada y mechada de pedancia.

Quedamos, pues, en que Radiguet no ha sido manoseado impudibundamente por el que suscribe, y en que mister Owen no está en condiciones de dar clases de castellano ni a los Pérez y López a quienes yo adiestro — un poco funambulescamente, quizás... en esgrimas áticobilbilitanas.

Mes civilitiés empressées. Y que el rey Clovis nos tenga a todos de su ungida mano.

Angel Samblancat

Como respaldo a uno de sus colaboradores, en seguida de esta carta, y en la misma página, se reproduce una "Respuesta de $E H P$ " que suena más a ironía que a respuesta:

En estos recargados pero amenos párrafos, el traductor Samblancat no invalida lo que el mexicanísimo Owen dijo en nuestro número anterior (pág. 121): "La obra ha sido traducida pésimamente al español por una persona que, probablemente, sabe muy bien su catalán, y que ha tratado de hacer superfluas adiciones a nuestro idioma con palabras tales como estrafalariedad, estuporoso, estrampillado, cuestionar por preguntar, parientes por padres, y a copia de en vez de a fuerza de".

Este artículo sobre Owen, traductor, como se aprecia, ha buscado, siquiera con sobriedad, saldar una deuda pendiente con Owen, en particular, y con la literatura mexicana, en general: me pregunto por qué las obras de un escritor no incluyen los productos de su labor mediadora como traductor, mientras sus textos críticos merecen un valor preponderante junto a la obra literaria propiamente dicha. Aun cuando resulta imposible hacer un seguimiento puntual de la influencia de las obras traducidas por un autor determinado, en este caso Owen, considero que su repercusión debe enmarcarse, primero, en las publicaciones que le dan cabida y, luego, dentro de la disputa por los espacios simbólicos en que se inscriben sus traducciones. En ese sentido, las mediaciones owenianas adquieren una relevancia incontestable, pues se hallan en el centro de las disputas ideológicas y literarias de los ańos 
veinte, y aun posteriores, que configuraron el devenir de la literatura mexicana moderna.

\section{BibLIOGRAFÍA}

Borges, Jorge Luis. "Cansinos y Las mil y una noches". La Nación, 10/julio/1960. En Textos recobrados. T. 3. Buenos Aires: Emecé, 2003: 53-55.

Bourdieu, Pierre. Las reglas del arte. Génesis y estructura del campo literario. Trad. Thomas Kauf. Barcelona: Anagrama, 1995.

Branch Cabell, James. The Witch-Woman. A Trilogy About Her. Nueva York: Farrar, Straus \& Young, 1948.

Caillois, Roger. "Actualidad de las sectas". El Hijo Pródigo. México. 4 (14), 15/mayo/1944: 89-92 [Trad. Gilberto Owen].

Cajero, Antonio. Gilberto Owen en Estampa. Textos olvidados y otros testimonios. México: El Colegio de San Luis, 2011.

Casanova, Pascale. La República Mundial de las Letras. Trad. Jaime Zulaika. Barcelona: Anagrama, 2001.

Dickinson, Emily. "Poemas. Versiones a ojo de Gilberto Owen". Lecturas Dominicales. El Tiempo. Bogotá. 29 [28]/abril/1934: 6-7.

"Documentos. Traducciones de teatro de arte hechas en México". En Antonio Magaña-Esquivel (ed.). "El Espectador" [Una revista mexicana de 1930]. México: Instituto Nacional de Bellas Artes, 1969.

García, Celenne y Antonio Cajero (eds.). Gilberto Owen en El Tiempo de Bogotá, prosas recuperadas (1933-1935). México: Universidad Autónoma del Estado de México / Porrúa, 2009.

García Maroto, Gabriel (ant.). Galería de los poetas nuevos de México [Nueva antología de poetas mexicanos]. Madrid: La Gaceta Literaria, 1928.

MÜNChausen, BARÓN DE. "Las sorprendentes aventuras del Barón de Munchausen". Trad. y adap. Gilberto Owen. Tercera Sección. El Tiempo, 7/ agosto/1935: 12.

"Notas. Se Recomienda". El Hijo Pródigo. México. 3 (10), 15/enero/1944: 60.

Owen, Gilberto. "Poesía y Revolución (Introducción a un Baedeker de la poesía mexicana actual [Escrito en 1931])". Lecturas Dominicales. El Tiempo, 25 [24]/febrero/1934a: 1.

Owen, Gilberto. "Emily Dickinson [Datos biográficos]". Lecturas Dominicales. El Tiempo. Bogotá. Núm. 536. 29 [28]/abril/1934b: 12.

Owen, Gilberto. "El diablo en el cuerpo. Raymond Radiguet", El Hijo Pródigo. México. 4 (14), 15/mayo/1944: 120-121. 
Owen, Gilberto. "Madrigal por Medusa”, "Libro de Ruth”. América. Revista Antológica. México. Núm. 50, diciembre/1950: 94-100.

Owen, Gilberto. Poesía y prosa. México: Universidad Nacional Autónoma de México, 1953.

Owen, Gilberto. Obras. México: Fondo de Cultura Económica, 1979.

Owen, Gilberto. "El Curioso Impertinente". Ulises. Núm. 5. Diciembre/1927: 26. En Antonio Cajero. Gilberto Owen en Estampa. Textos olvidados y otros testimonios. México: El Colegio de San Luis, 2011: 83-84.

PArish, Lestrois. "Lázaro Cárdenas, un indio asceta”. Trad. Gilberto Owen. Segunda Sección. El Tiempo, 19/enero/1935: 18.

Quirarte, Vicente. Invitación a Gilberto Owen. México: Universidad Nacional Autónoma de México / El Equilibrista, 2007.

“Respuesta de EHP”. El Hijo Pródigo. México. 4 (15), junio/1944: 187.

Rojas Garcidueñas, José. "Gilberto Owen. Notas y documentos de su vida y su obra”. Anales del Instituto de Investigaciones Estéticas. 10 (40), 1971: 75-100.

Rojas Rosillo, IsaAc. “Un canto a China”. Letras de México. México (4) 17. 1/mayo/1944: 6.

Samblancat, Ángel. "Una carta de traductor". El Hijo Pródigo. México. 4 (15), junio/1944: 186-187.

Sánchez Barbudo, Antonio. "China en armas". El Hijo Pródigo. México. 5 (16), julio/1944: 57.

Secondo, Rosso di San. Lazarina entre cuchillos [I], El Hijo Pródigo. 13 (40), 15/julio/1946: 48-55 [Trad. Gilberto Owen y Agustín Lazo].

Secondo, Rosso di San. Lazarina entre cuchillos [II], El Hijo Pródigo. (13) 41, 15/agosto/1946: 93-103 [Trad. Gilberto Owen y Agustín Lazo].

Smedley, Agnes. "El automóvil núm. 1469”. El Hijo Pródigo. 3 (10), enero/1944: 35-39 [Trad. Gilberto Owen].

Smedley, Agnes. China en armas. Trad. Gilberto Owen. México: Nuevo Mundo, 1944.

"El Tiempo para los niños”. El Tiempo. Bogotá, 5/agosto/1935: 5.

Velázquez Bringas, Esperanza y Rafael Heliodoro Valle. Índice de escritores. México: Herrero, 1928.

Valéry, Paul. "Pequeños textos. Comentarios de grabados". Contemporáneos. México. Núm. 4, septiembre/1928: 34-39 [Trad. Gilberto Owen].

FeCha de RECEPCIÓN: 12 de noviembre 2013.

FECHA DE ACEPTACión: 29 de enero de 2014. 